\title{
Activity of [des-Aspartyl ${ }^{1}$-Angiotensin II in Primary Aldosteronism
}

\author{
Robert M. Carey, Carlos R. Ayers, E. Darracott Vaughan, Jr., \\ Michael J. Peach, and Steven M. Herf, Departments of Internal Medicine, \\ Urology, and Pharmacology, University of Virginia School of Medicine, \\ Charlottesville, Virginia 22908
}

A B S TRACT This study describes the effects of [des-Aspartyl $\left.{ }^{1}\right]$-angiotensin II ([des-Asp]-AII) on blood pressure and aldosterone production in patients with primary aldosteronism due to aldosterone-producing adrenal adenoma (APA) and idiopathic adrenal hyperplasia (IHA), and in normotensive control subjects. 10 patients with primary aldosteronism, 7 with APA and 3 with IHA, and 6 normotensive control subjects were placed on a constant 150 -meq sodium diet for 4 days. [des-Asp]-AII was infused for $30 \mathrm{~min}$ at 6,12 , and $18 \mathrm{pmol} / \mathrm{kg}$ per min. Three groups of patients were identified on the basis of aldosterone response to [des-Asp]-AII. Group I, composed of normotensive control subjects, showed incremental increases in plasma aldosterone concentration from $6 \pm 1$ to $14 \pm 3$ $\mathrm{ng} / 100 \mathrm{ml}(P<0.01)$ with [des-Asp]-AII infusion. Group II, composed of patients with primary aldosteronism, showed incremental increases in plasma aldosterone concentration from $33 \pm 8$ to $65 \pm 13 \mathrm{ng} /$ $100 \mathrm{ml}(P<0.05)$ with $12 \mathrm{pmol} / \mathrm{kg}$ per min of [desAsp]-AII. Group III, also composed of patients with primary aldosteronism, showed no increase of plasma aldosterone concentration with [des-Asp]-AII. Groups I and II showed similar percentage increases in plasma aldosterone concentration $(P=\mathrm{NS})$. Group III showed significantly lower aldosterone responses than group I $(P<0.01)$. Group II included all patients with IHA and two patients with APA. Group III included only patients with APA. The blood pressure responses to [des-Asp]-AII of subjects in group I did not differ significantly from those of groups II or III.

Thus, patients with IHA and a subgroup of patients with APA showed responsiveness to [des-Asp]-AII which was limited to adrenal cortical stimulation of aldosterone biosynthesis. This suggests that adrenal

Dr. Carey is an Established Investigator of the American Heart Association.

Received for publication 26 June 1978 and in revised form 8 December 1978. responsiveness to angiotensin is a major control mechanism in some forms of primary aldosteronism. The differential adrenal responsiveness to [des-Asp]AII in patients with APA indicates either that there are two distinct subpopulations of APA, or that alteration in tumor response to angiotensin occurs during the natural progression of the disease history.

\section{INTRODUCTION}

Primary aldosteronism is a condition in which overproduction of aldosterone appears relatively independent of the renin-angiotensin system (1). Four subtypes of primary aldosteronism have been identified. These include aldosterone-producing adenoma (APA), ${ }^{1}$ idiopathic hyperaldosteronism (IHA), glucocorticoid remedial hyperaldosteronism, and indeterminant hyperaldosteronism (2). APA and IHA account for the majority of primary aldosteronism observed in the adult population (2). Aldosterone production in patients with IHA increases with stimulation of the renin-angiotensin system whereas aldosterone production in APA does not (3-9). Direct stimulation of aldosterone secretion by exogenous angiotensin II (AII) has been attempted in patients with primary aldosteronism, but the results have been inconclusive because excessive pressor responses to AII occur before a dose adequate to stimulate aldosterone can be administered (3).

The C-terminal heptapeptide fragment of AII,

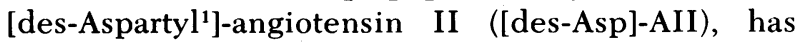
$25-100 \%$ of the aldosterone-stimulating potency but only $\sim 25 \%$ of the pressor potency of AII in normotensive man $(10,11)$. Thus, [des-Asp]-AII might be more suitable than AII for studies of the effects of angiotensin-induced aldosterone production in pri-

${ }^{1}$ Abbreviations used in this paper: AII, angiotensin II; APA, aldosterone-producing adenoma; [des-Asp]-AII, [desAspartyl']-angiotensin II; IHA, idiopathic hyperaldosteronism. 
mary aldosteronism because the dose of [des-Asp]AII would not be as limited by unacceptable pressor responses. We hypothesized that [des-Asp]-AII would stimulate aldosterone production in patients with IHA but not those with APA. The present study was designed to examine the effects of [des-Asp]-AII on blood pressure and aldosterone production in patients with these two forms of primary aldosteronism.

\section{METHODS}

Patients and study protocol. 10 patients with primary aldosteronism and 6 normal control subjects were studied. The diagnosis of primary aldosteronism was made on the following basis: (a) sustained hypertension (blood pressure $>160 / 95 \mathrm{~mm} \mathrm{Hg}$ ); (b) unprovoked hypokalemia (serum potassium < $3.5 \mathrm{meq} / \mathrm{liter}) ;(c)$ inappropriate kaluresis $(24-\mathrm{h}$ urinary potassium excretion $>40 \mathrm{meq})$; $(d)$ suppressed plasma renin activity $(<2 \mathrm{ng}$ of angiotensin $\mathrm{I} / \mathrm{ml}$ per $\mathrm{h}$ ) at 11:00 a.m. after $3 \mathrm{~h}$ of upright posture and $40 \mathrm{mg}$ oral furosemide at 6 p.m., 10 p.m., and 8 a.m. according to the method of Carey et al. (12); and (e) elevated plasma aldosterone concentration and 24-h urinary aldosterone excretion indexed against 24-h urinary sodium excretion subsequent to correction of hypokalemia with supplemental oral potassium chloride. The aldosterone/sodium index was referenced against the inverse hyperbolic relationship between ambulatory plasma aldosterone concentration or urinary aldosterone excretion and concurrent 24-h urinary sodium excretion found in 15 normal subjects. Plasma aldosterone concentrations were measured in each of the 15 normal subjects after $5 \mathrm{~d}$ of different sodium balances: $10,50,100$, 150 , and 200 meq sodium intake/day (13).

The diagnosis of APA was based on absence of an increase in plasma aldosterone concentration in response to $4 \mathrm{~h}$ of upright posture, lateralization of uptake of $\left[{ }^{131} I\right]$ iodomethylnorcholesterol to one side on adrenal scan, and normalization of blood pressure and serum potassium concentration after $6 \mathrm{wk}$ of spironolactone $100 \mathrm{mg}$ four times daily (q.i.d.) (14). All patients with an APA had pathological documentation of an adrenal adenoma and correction of their hypertension and hypokalemia after excision of the adenoma. Three patients judged to have IHA had increases of plasma aldosterone concentration over $25 \%$ of base line in response to $4 \mathrm{~h}$ of upright posture and unequivocal bilateral visualization on adrenal scan. Adrenal scanning was performed with $\left[{ }^{131} \mathrm{I}\right]$ iodomethylnorcholesterol $3 \mathrm{~d}$ after injection of the radioisotope during dexamethasone $(0.5 \mathrm{mg}$ q.i.d.) suppression and was repeated 4 days after discontinuation of dexamethasone. All patients were given Lugol's iodine solution five drops twice daily (b.i.d.) for 3 days before and 2 wk after the injection of the isotope. [ ${ }^{131}$ I] Iodomethylnorcholesterol (NP-59) was obtained from the Nuclear Pharmacy at the University of Michigan, Ann Arbor, Mich., and scanning was performed with an HP Searle gamma camera. (Searle Diagnostics Inc., Des Plaines, Ill.). The patients underwent mineralocorticoid and glucocorticoid suppression tests to exclude indeterminant hyperaldosteronism and glucocorticoid remedial hyperaldosteronism. Mineralocorticoid and glucocorticoid suppression tests were performed by determining plasma aldosterone concentration, 24-h urinary aldosterone excretion, blood pressure at 4 -h intervals, and plasma potassium concentrations after 3 days of fludrocortisone acetate (Florinef, E. R. Squibb \& Sons, Princeton, N. J.) $0.15 \mathrm{mg}$ b.i.d. and dexamethasone $0.5 \mathrm{mg}$ q.i.d., respectively.

All medications were discontinued and the patients were given $60 \mathrm{meq} / \mathrm{d}$ of supplemental potassium chloride for 6 wk before admission to the Clinical Research Center. Written informed consent was obtained from all patients. On admission to the Clinical Research Center all patients and normotensive control subjects were given a constant daily diet containing $150 \mathrm{meq}$ sodium, $60 \mathrm{meq}$ potassium, $1 \mathrm{~g}$ protein $/ \mathrm{kg}$, and 2,860 cal for $4 \mathrm{~d}$ before the [des-Asp]AII infusion study. Patients with primary aldosteronism were given 60-160 meq of supplemental potassium chloride until serum potassium was normalized. Consecutive 24-h urine samples were collected for $4 \mathrm{~d}$ of the diet and analyzed for sodium and potassium. No food was given after midnight on the day of the [des-Asp]-AII infusion and the patients remained supine until completion of the infusion. At 7:00 a.m. on the day of the infusion, a heparin lock for obtaining blood samples was inserted into the left antecubital vein and an intravenous infusion of $5 \%$ dextrose in water at $0.5 \mathrm{ml} / \mathrm{min}$ was begun in the right antecubital vein. At 8:00 a.m. blood pressure monitoring with an Arteriosonde (Hoffmann-La Roche, Inc., Medical Electronics Div., Nutley, N. J.) was begun and readings were obtained every 2 min until completion of the study. A blood pressure cuff (with a width approximately two-thirds the width of the arm and a length such that the bladder completely encircled the arm) was wrapped snugly around the left arm. The Arteriosonde was calibrated against a random-zero mercury sphygmomanometer. Blood pressures are expressed as the mean of 15 readings obtained during the 30-min control period and each infusion period. At 8:00 a.m. control blood samples were obtained for the concentrations of serum potassium, plasma aldosterone, and cortisol, as well as plasma renin activity. A repeat control blood sample for plasma aldosterone, cortisol, and serum potassium concentration was obtained at 8:30 a.m. After completion of blood sampling at 8:30 a.m. an intravenous infusion of [des-Asp]-AII at a rate of $6 \mathrm{pmol} / \mathrm{kg}$ per min was begun. Plasma samples for aldosterone, cortisol, and potassium determinations were obtained at 30 -min intervals until completion of the study. The heptapeptide, [des-Asp]-AII, was infused at three successive infusion rates of 6,12 , and 18 $\mathrm{pmol} / \mathrm{kg}$ per $\mathrm{min}$ for $30 \mathrm{~min}$ at each dose level. If an increase in mean arterial blood pressure of $20 \mathrm{~mm} \mathrm{Hg}$ was observed, the infusion was terminated. Three of the patients with primary aldosteronism had such an increase in blood pressure, and thus received only two cumulative doses of 6 and $12 \mathrm{pmol} / \mathrm{kg}$ per min of the heptapeptide. A blood sample for analysis of plasma renin activity was obtained upon completion of the infusion.

Synthetic [des-Asp ${ }^{1}$, Ile ${ }^{5}$ ]-AII ([des-Asp]-AII) was provided by Beckman Instruments, Inc., Fullerton, Calif. The peptide was diluted in sterile $\mathrm{H}_{2} \mathrm{O}$, filtered with a $0.22-\mu \mathrm{m}$ Millipore filter (Millipore Corp., Bedford, Mass.), and stored at $4^{\circ} \mathrm{C}$ in sterile vials at a concentration of $100 \mu \mathrm{g} / \mathrm{ml}$.

Analytical methods. All blood samples were placed into tubes prechilled in ice, centrifuged immediately, and plasma separated and frozen until the time of assay. Samples used for plasma renin activity and aldosterone were anticoagulated with EDTA. Serum and urine potassium and sodium concentrations were measured by flame photometry (model 143, Instrumentation Laboratory, Inc., Lexington, Mass.). Aldosterone concentration was measured by the radioimmunoassay method of Bühler et al. (15). After incubation, plasma renin activity was determined by radioimmunoassay of angiotensin I generated as described by Sealey et al. (16). Plasma cortisol levels were determined by the fluorometric method of Mattingly (17).

Statistical analysis. The results are expressed as mean \pm 1 SE. Statistical analysis was carried out with the Student's $t$ 
test for paired data and the standard $t$ test for intergroup comparisons, and $P$ values of $<0.05$ are considered significant.

\section{RESULTS}

Characteristics of the patients. The individual results of studies by which the diagnosis of APA or IHA was achieved are shown in Table I. The mean values $\pm \mathrm{SE}$ for all of these patients are: systolic blood pressure $176 \pm 3 \mathrm{~mm} \mathrm{Hg}$; diastolic blood pressure $109 \pm 3 \mathrm{~mm} \mathrm{Hg}$; serum potassium $2.9 \pm 0.1 \mathrm{meq} / \mathrm{liter}$; 24-h urinary potassium excretion $71 \pm 5 \mathrm{meq}$; plasma renin activity after $120 \mathrm{mg}$ of furosemide and $3 \mathrm{~h}$ of upright posture $0.82 \pm 0.24 \mathrm{ng} /$ angiotensin I per ml per $\mathrm{h}$; basal supine plasma aldosterone concentration $34 \pm 3$ $\mathrm{ng} / 100 \mathrm{ml} ; 24$-h urinary aldosterone excretion $40 \pm 5$ $\mu \mathrm{g}$; 24-h urinary sodium excretion $152 \pm 13 \mathrm{meq}$; urinary aldosterone excretion on day 3 of Florinef administration ( $0.15 \mathrm{mg}$ b.i.d.) $40 \pm 4 \mu \mathrm{g} / 24 \mathrm{~h}$; and urinary aldosterone excretion on day 3 of dexamethasone administration ( $0.5 \mathrm{mg}$ q.i.d.) $36 \pm 4 \mu \mathrm{g} / 24 \mathrm{~h}$.

The patients were divided into groups based on their aldosterone response to the [des-Asp]-AII. Group I is composed of six normotensive control subjects. Group II is composed of five patients with primary aldosteronism who responded to [des-Asp]-AII with an incremental increase in plasma aldosterone concentration. Group III is composed of five patients with primary aldosteronism who did not respond with an increase in plasma aldosterone concentration to [desAsp]-AII.

The characteristics of each group including weight, mean arterial blood pressure, 24-h urinary sodium and potassium excretion on day 5 of the 150 -meq $\mathrm{Na}$ diet, basal supine plasma aldosterone concentration, and basal supine plasma renin activity on the day of [des-Asp]-AII infusion are shown in Table II. The mean weight of patients in group II was significantly greater $(P<0.05)$ than controls. The urinary sodium excretion of groups II and III was less and potassium excretion greater than control $(P<0.05, P<0.01$, respectively) reflecting the increased aldosterone production of these patients. Mean arterial blood pres-

TABLE I

Diagnostic Tests of the Patients with Primary Aldosteronism $(n=10)$

\begin{tabular}{|c|c|c|c|c|c|c|c|c|c|c|c|c|}
\hline \multirow[b]{3}{*}{$\begin{array}{l}\text { Patient } \\
\text { no. }\end{array}$} & \multirow[b]{3}{*}{ Diagnosis } & \multirow[b]{3}{*}{$\begin{array}{l}\text { Blood } \\
\text { pressure }\end{array}$} & \multirow[b]{3}{*}{$\begin{array}{c}\text { Serum } \\
\mathrm{K}+\end{array}$} & \multirow[b]{3}{*}{$\begin{array}{c}\text { Urine } \\
\mathrm{K}+\end{array}$} & \multirow{3}{*}{$\begin{array}{l}\text { Plasma } \\
\text { renin } \\
\text { activity }\end{array}$} & \multirow{3}{*}{$\begin{array}{l}\text { Plasma } \\
\text { aldo- } \\
\text { sterone } \\
\text { concen- } \\
\text { tration }\end{array}$} & \multirow{2}{*}{\multicolumn{2}{|c|}{ Urine }} & \multicolumn{2}{|c|}{ Urine aldosterone } & \multirow{3}{*}{$\begin{array}{l}\text { Adrenal } \\
\text { scan } \\
\text { results }\end{array}$} & \multirow[b]{3}{*}{$\begin{array}{c}\text { Surgical } \\
\text { results }\end{array}$} \\
\hline & & & & & & & & & & After & & \\
\hline & & & & & & & $\begin{array}{c}\text { Aldo- } \\
\text { sterone }\end{array}$ & $\mathrm{Na}$ & $\begin{array}{c}\text { After } \\
\text { Fluorinef }\end{array}$ & $\begin{array}{l}\text { metha- } \\
\text { sone }\end{array}$ & & \\
\hline \multicolumn{13}{|l|}{ Group II } \\
\hline 1 & APA & $\frac{170}{100}$ & 3.3 & 58 & 1.59 & 49 & 30 & 108 & 46 & 48 & $\begin{array}{l}\text { Asym. } \\
\qquad \mathrm{L}>\mathrm{R}\end{array}$ & L-adenoma \\
\hline 2 & APA & $\frac{170}{110}$ & 3.1 & 72 & 0.15 & 36 & 75 & 95 & 34 & 31 & $\begin{array}{l}\text { Asym. } \\
\qquad \mathrm{L}>\mathrm{R}\end{array}$ & L-adenoma \\
\hline 3 & IHA & $\frac{170}{100}$ & 2.8 & 64 & 0.50 & 29 & 61 & 167 & 68 & 64 & Bilat. & - \\
\hline 4 & IHA & $\frac{180}{120}$ & 3.2 & 64 & 0.49 & 49 & 44 & 143 & 47 & 29 & Bilat. & - \\
\hline 5 & IHA & $\frac{190}{105}$ & 2.8 & 100 & 0.35 & 42 & 28 & 220 & 28 & 18 & Bilat. & - \\
\hline \multicolumn{13}{|l|}{ Group III } \\
\hline 6 & APA & $\frac{170}{101}$ & 3.5 & 97 & 1.99 & 26 & 34 & 116 & 49 & 33 & $\begin{array}{l}\text { Asym. } \\
\quad \mathrm{R}>\mathrm{L}\end{array}$ & R-adenoma \\
\hline 7 & APA & $\frac{190}{120}$ & 2.5 & 73 & 0.14 & 24 & 18 & 212 & 23 & 20 & Unilat. R & R-adenoma \\
\hline 8 & APA & $\frac{170}{106}$ & 2.8 & 68 & 0.34 & 28 & 34 & 175 & 35 & 31 & $\begin{array}{l}\text { Asym. } \\
\qquad \mathrm{R}>\mathrm{L}\end{array}$ & R-adenoma \\
\hline 9 & APA & $\frac{180}{120}$ & 2.9 & 54 & 0.94 & 34 & 39 & 124 & 36 & 41 & $\begin{array}{l}\text { Asym. } \\
\quad \mathbf{L}>\mathbf{R}\end{array}$ & L-adenoma \\
\hline 10 & APA & $\frac{170}{110}$ & 2.0 & 57 & 1.71 & 23 & 33 & 156 & 34 & 40 & $\begin{array}{l}\text { Asym. } \\
\quad \mathrm{L}>\mathbf{R}\end{array}$ & L-adenoma \\
\hline
\end{tabular}


TABLE II

Characteristics of the Patients on the 5th d of Constant 150 meq Sodium Intake

\begin{tabular}{|c|c|c|c|}
\hline & $\begin{array}{l}\text { Group I } \\
(n=6)\end{array}$ & $\begin{array}{c}\text { Group II } \\
(n=5)\end{array}$ & $\begin{array}{l}\text { Group III } \\
(n=5)\end{array}$ \\
\hline Weight, $k g$ & $87 \pm 2$ & $93 \pm 8^{*}$ & $80 \pm 1$ \\
\hline $\begin{array}{l}\text { 24-h urine } \mathrm{Na} \text {, } \\
\text { meq } \\
\text { 24-h urine } \mathrm{K}\end{array}$ & $155 \pm 2$ & $142 \pm 6^{*}$ & $137 \pm 10^{*}$ \\
\hline $\begin{array}{l}\text { meq } \\
\text { Mean arterial BP }\end{array}$ & $64 \pm 3$ & $130 \pm 22 \ddagger$ & $111 \pm 18$ \\
\hline $\begin{array}{l}\text { Mean arterial BP, } \\
\quad m m \mathrm{Hg} \\
\text { Plasma renin }\end{array}$ & $83 \pm 2$ & $124 \pm 6 \S$ & $133 \pm 3 \S$ \\
\hline $\begin{array}{l}\text { activity, } \\
\text { ng AI/ml/h } \\
\text { Plasma }\end{array}$ & $1.93 \pm 0.30$ & $0.66 \pm 0.33^{*}$ & $0.37 \pm 0.08$ \\
\hline $\begin{array}{l}\text { aldosterone, } \\
n g / 100 \mathrm{ml}\end{array}$ & $6 \pm 1$ & $33 \pm 9 \ddagger$ & $38 \pm 8 \S$ \\
\hline
\end{tabular}

* Values significantly different from those of group I (normal control subjects), $P<0.05$.

$\$ P<0.01$.

$\S P<0.001$.

sure and plasma aldosterone concentration were higher and plasma renin activity lower in groups II and III than in group I (normotensive control subjects).

Aldosterone and renin activity responses to upright posture. The individual responses of plasma aldosterone concentration to $4 \mathrm{~h}$ of upright posture for patients with primary aldosteronism are depicted in Fig. 1. All patients with IHA showed a marked postural increase in plasma aldosterone concentration whereas patients with APA showed no increase or a decline $(P<0.01)$. The individual responses of plasma renin activity to $4 \mathrm{~h}$ of upright posture for patients with primary aldosteronism are shown in Fig. 2. The mean plasma renin activity for all patients with primary aldosteronism showed a significant increase from $0.32 \pm 0.10$ to $0.66 \pm 0.19 \mathrm{ng} / \mathrm{ml}$ per $\mathrm{h}(P<0.01)$. Plasma renin activity of subjects with APA increased from $0.36 \pm 0.15$ to $0.74 \pm 0.26 \mathrm{ng} / \mathrm{ml}$ per $\mathrm{h}(P<0.05)$ and plasma renin activity of subjects with IHA increased from $0.23 \pm 0.04$ to $0.47 \pm 0.08 \mathrm{ng} / \mathrm{ml}$ per $\mathrm{h}(P<0.05)$.

Plasma aldosterone and blood pressure responses to [des-Asp]-AII. Plasma aldosterone concentrations in response to 6,12 , and $18 \mathrm{pmol} / \mathrm{kg}$ per min of [des-Asp]-AII for the three groups are shown in Fig. 3. The individual aldosterone responses to [desAsp]-AII for all patients with primary aldosteronism are shown in Fig. 4. In group I (normotensive control subjects) an increase in plasma aldosterone concentration of $3 \pm 1 \mathrm{ng} / 100 \mathrm{ml}(P<0.05), 6 \pm 1 \mathrm{ng} / 100 \mathrm{ml}$ $(P<0.01)$, and $8 \pm 1 \mathrm{ng} / 100 \mathrm{ml}(P<0.01)$ was observed at 6,12 , and $18 \mathrm{pmol} / \mathrm{kg}$ per min of [des-Asp]-AII, respectively. In group II ([des-Asp]-AII responsive),

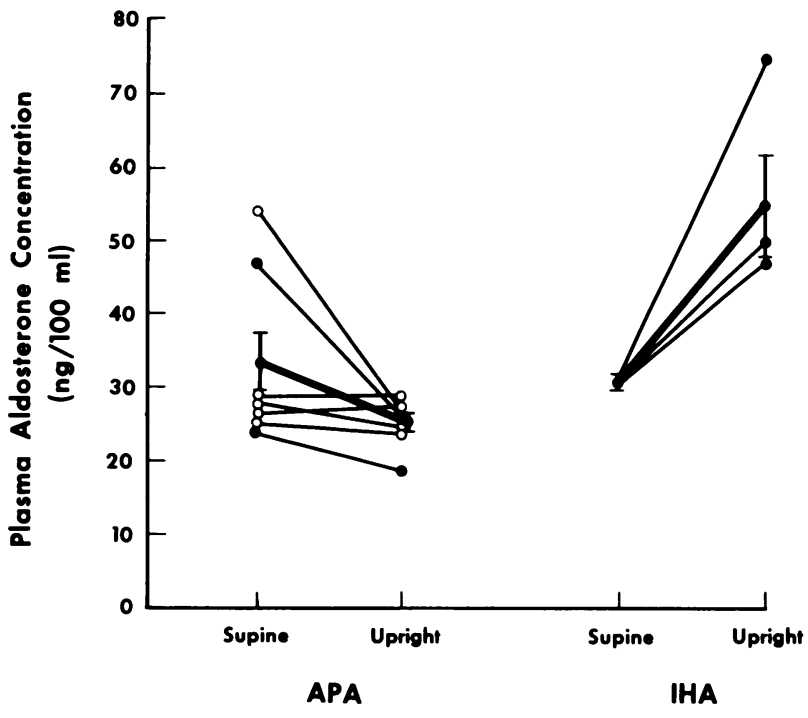

FIGURE 1 Aldosterone responses to $4 \mathrm{~h}$ of upright posture in subjects with primary aldosteronism due to APA and IHA. Mean values are plotted with heavy bars; 0 , group II; and $\bigcirc$, group III.

an increase of plasma aldosterone concentration of $21 \pm 11 \mathrm{ng} / 100 \mathrm{ml}(P<0.05)$ at $6 \mathrm{pmol} / \mathrm{kg}$ per min and $32 \pm 12 \mathrm{ng} / 100 \mathrm{ml}(P<0.05)$ at $12 \mathrm{pmol} / \mathrm{kg}$ per min was observed with [des-Asp]-AII infusion. The two subjects who received [des-Asp]-AII at $18 \mathrm{pmol} / \mathrm{kg}$ per $\mathrm{min}$ had a further increase of plasma aldosterone concentration of $7 \pm 2 \mathrm{ng} / 100 \mathrm{ml}$. In group III ([des-Asp]-AII unresponsive), the changes in plasma aldosterone concen-

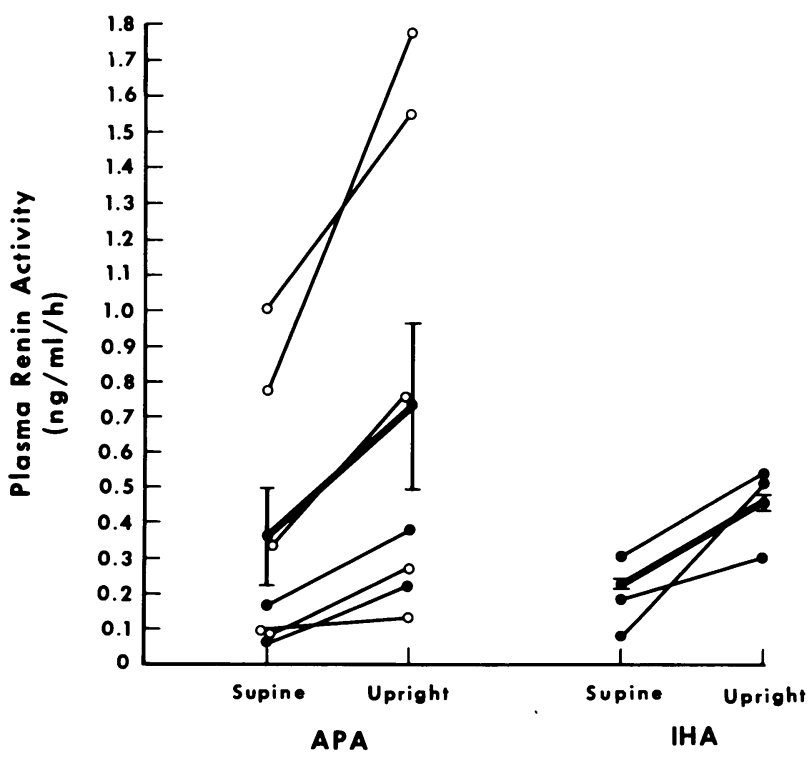

FIGURE 2 Renin responses to $4 \mathrm{~h}$ of upright posture in subjects with primary aldosteronism due to APA and IHA. Mean values are plotted with heavy bars; 0 , group II; and $\bigcirc$, group III. 


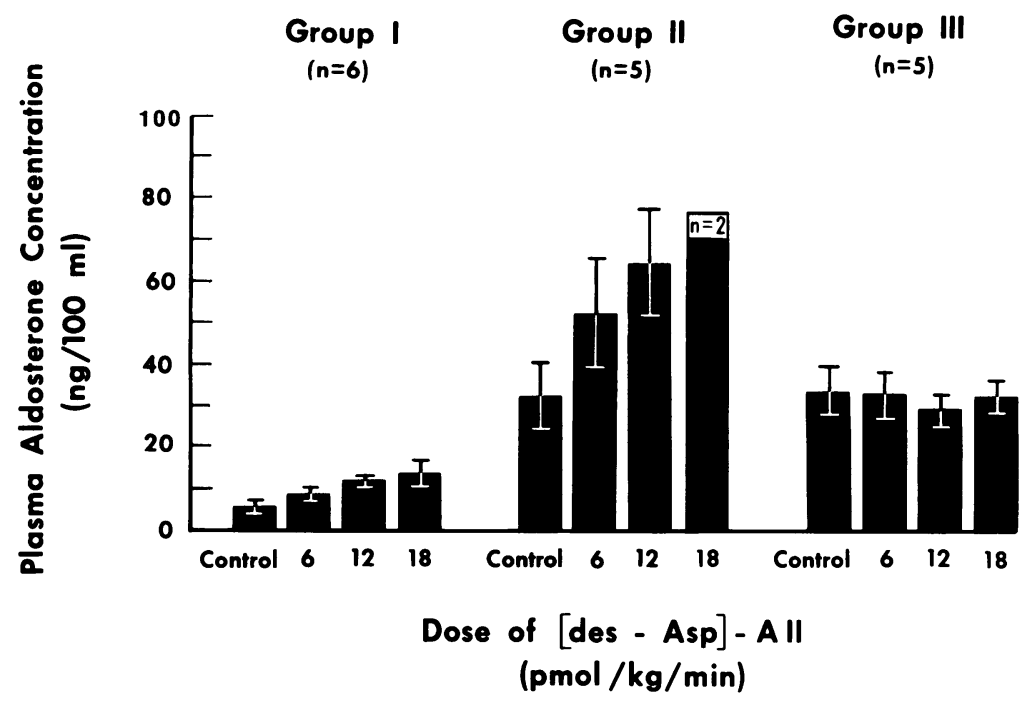

FIGURE 3 Aldosterone responses of subjects in the three study groups to [des-Asp]-AII infusion. Three of the subjects in group II received two cumulative doses of heptapeptide. All other subjects received three cumulative doses of heptapeptide.

tration of $-1 \pm 1,-5 \pm 3$, and $-1 \pm 1 \mathrm{ng} / 100 \mathrm{ml}$, with each successive dose of [des-Asp]-AII, respectively, were not significantly different from control values. The increment of plasma aldosterone concentration of $32 \pm 12 \mathrm{ng} / 100 \mathrm{ml}$ in response to $12 \mathrm{pmol} / \mathrm{kg}$ per min of [des-Asp]-AII in group II was significantly greater than the increase of $6 \pm 1 \mathrm{ng} / 100 \mathrm{ml}$ in group $\mathrm{I}(P$ $<0.05$ ). However, at $12 \mathrm{pmol} / \mathrm{kg}$ per $\mathrm{min}$ of [desAsp]-AII, the percentage increase in plasma aldosterone concentration for group I was $163 \pm 65 \%$ compared with $120 \pm 40 \%$ for group II. The percentage change of plasma aldosterone concentration of group I was not significantly different from that of group II. Similarly, the percentage increase of plasma aldosterone of $169 \pm 47 \%$ for the patients with IHA was not different from that of group I. The increment of plasma aldosterone concentration in group I was significantly greater than that of group III at the 6,12 , and 18 $\mathrm{pmol} / \mathrm{kg}$ per min dose $(P<0.05, P<0.01$, and $P$ $<0.01$, respectively).

The mean arterial blood pressure values for the three groups in the basal state and during 6, 12, and 18 $\mathrm{pmol} / \mathrm{kg}$ per min of [des-Asp]-AII infusion are depicted in Fig. 5. In group I (normotensive control subjects), the incremental increase in mean arterial pressure above base line was $7 \pm 2 \mathrm{~mm} \mathrm{Hg}(P<0.01)$ at 6 $\mathrm{pmol} / \mathrm{kg}$ per min, $12 \pm 2 \mathrm{~mm} \mathrm{Hg}(P<0.01)$ at 12 $\mathrm{pmol} / \mathrm{kg}$ per min, and $14 \pm 2 \mathrm{~mm} \mathrm{Hg}(P<0.01)$ at 18 $\mathrm{pmol} / \mathrm{kg}$ per $\min$ of [des-Asp]-AII. In group II ([des-Asp]-AII responsive), the increases in mean arterial pressure with 6 and $12 \mathrm{pmol} / \mathrm{kg}$ per min of [des-Asp]-AII were $9 \pm 2$ and $17 \pm 3 \mathrm{~mm} \mathrm{Hg}$, respectively $(P<0.01)$. The two subjects who received [des-Asp]-AII at $18 \mathrm{pmol} / \mathrm{kg}$ per min had a further decrease of mean arterial blood pressure of $3 \pm 1 \mathrm{~mm}$ Hg. In group III ([des-Asp]-AII unresponsive), the [des-Asp]-AII-induced increases in mean arterial pressure were $7 \pm 3(P<0.01), 14 \pm 2(P<0.01)$, and $16 \pm 2$ $(P<0.01) \mathrm{mm} \mathrm{Hg}$. There were no significant differences between groups I and II or between groups I and III with respect to the increment or percentage change of blood pressure in response to any dose level of [des-Asp]-AII.

Responses of potassium, cortisol, and renin to [des-Asp]-AII. Basal serum potassium and plasma cortisol values were $3.8 \pm 0.1 \mathrm{meq} / \mathrm{liter}$ and $19 \pm 2$ $\mu \mathrm{g} / 100 \mathrm{ml}$, respectively, for subjects in group I (normotensive controls) and were $3.7 \pm 0.1 \mathrm{meq} / \mathrm{liter}$ and $21 \pm 3 \mu \mathrm{g} / 100 \mathrm{ml}$, respectively, for patients in group II ([des-Asp]-AII responsive).

Serum potassium and plasma cortisol values at the completion of the [des-Asp]-AII infusions for group I were $3.7 \pm 0.1 \mathrm{meq} / \mathrm{liter}(P=\mathrm{NS})$ and $19 \pm 2 \mu \mathrm{g} / 100$ $\mathrm{ml}(P=\mathrm{NS})$, respectively, and for group II were $3.8 \pm 1 \mathrm{meq} / \mathrm{liter}(P=\mathrm{NS})$ and $20 \pm 2 \mu \mathrm{g} / 100 \mathrm{ml}(P$ $=\mathrm{NS}$ ), respectively. In group I, [des-Asp]-AII infusion suppressed plasma renin activity from $1.92 \pm 0.30$ to $0.76 \pm 0.11 \mathrm{ng} / \mathrm{ml}$ per $\mathrm{h}(P<0.01)$. In contrast, the values in groups II and III were respectively 0.66 \pm 0.31 and $0.37 \pm 0.08 \mathrm{ng} / \mathrm{ml}$ per $\mathrm{h}$ before and $0.35 \pm 0.09$ and $0.30 \pm 0.09 \mathrm{ng} / \mathrm{ml}$ per $\mathrm{h}$ after [des-Asp]-AII infusion. These changes were not significant.

\section{DISCUSSION}

The present study identifies two subgroups of patients with primary aldosteronism on the basis of their responses to [des-Asp]-AII. We hypothesized that pa- 


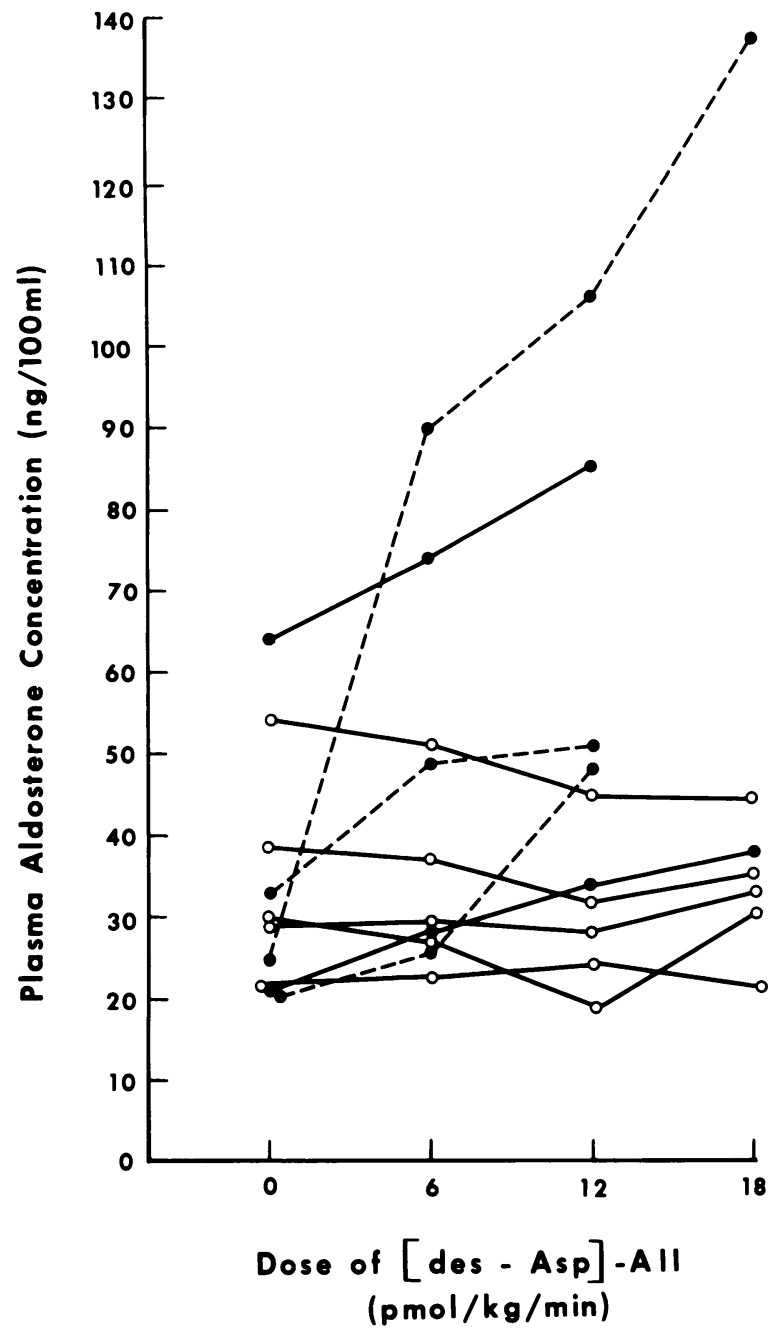

FIGURE 4 Individual aldosterone responses of subjects with primary aldosteronism due to APA (solid lines) and IHA (dashed lines) to [des-Asp]-AII infusion ( $\bullet$ group II; $O$, group III). Seven subjects received three cumulative doses and three subjects received two cumulative doses of heptapeptide.

tients with IHA would respond to [des-Asp]-AII, since the response of aldosterone to endogenous stimulation of renin/angiotensin with upright posture is apparent (3-9). We further hypothesized that patients with APA would be unlikely to display an aldosterone response to [des-Asp]-AII infusion, because previous attempts in these patients to stimulate the endogenous reninangiotensin system by upright posture or sodium deprivation have failed to stimulate aldosterone production (3-9). Thus, our observed stimulation of aldosterone with [des-Asp]-AII in IHA was as anticipated. However, aldosterone stimulation with [des-Asp]-AII in two of seven patients with pathologically confirmed APA was unexpected. This observation documents the existence of a subpopulation of APA which retains responsiveness to an angiotensin stimulus. The two [des-Asp]-AII-responsive patients with APA could not be separated from the seven [des-Asp]-AII-nonresponsive patients with APA with respect to blood pressure, sodium or potassium balance, basal plasma renin activity or aldosterone concentration, or responses of renin or aldosterone to upright posture, mineralocorticoid or glucocorticoid administration, or adrenal pathology.

Previous studies from this laboratory have demonstrated the pressor and steroidogenic properties of the heptapeptide, [des-Asp]-AII, in normal human subjects (11). In man, similar to experimental animals, [desAsp]-AII was demonstrated to have $\cong 25 \%$ of the pressor potency of AII. However, in contrast to studies in experimental animals showing similar aldosteronestimulating potency of the two peptides, we found in normal man that [des-Asp]-AII has only $\cong 2.5 \%$ of the steroidogenic activity of AII (11). These results differ from those reported in a preliminary communication by Kono et al. (10), who found that [des-Asp]-AII and AII were approximately equivalent in stimulating aldosterone production in man.

In the present study, we observed a similar blood pressure response, both in terms of increment and percentage change, in all three groups of subjects with infusion of [des-Asp]-AII. In spite of the 150-meq/d constant sodium intake, both groups of patients with primary aldosteronism had significantly greater sodium retention as manifested by diminished urinary sodium excretion. Similarly, suppression of the endogenous renin-angiotensin system, reflected by lower basal plasma renin activity, was significantly greater in both groups of patients with primary aldosteronism than the control group. Sodium retention and suppression of the endogenous renin-angiotensin system have been shown to augment the pressor response to administered AII (18). However, these observations have been made over a wide range of sodium intake in subjects with normal and high plasma renin activity. The results of the present study suggest that increased pressor responsiveness to angiotensin is not a universal finding in subjects with low plasma renin activity. These results are in agreement with the reported failure to achieve greater than normal increases in blood pressure in patients with low renin essential hypertension with AII administration (19).

The differential effect of upright posture on plasma aldosterone concentration in patients with primary aldosteronism due to IHA vs. APA is well documented (3-8). It is interesting that postural responsiveness of aldosterone failed to identify all patients who responded to [des-Asp]-AII. The responsiveness of the adrenal cortex to exogenous angiotensin in some patients with APA who did not respond to upright posture with an increase in plasma aldosterone 


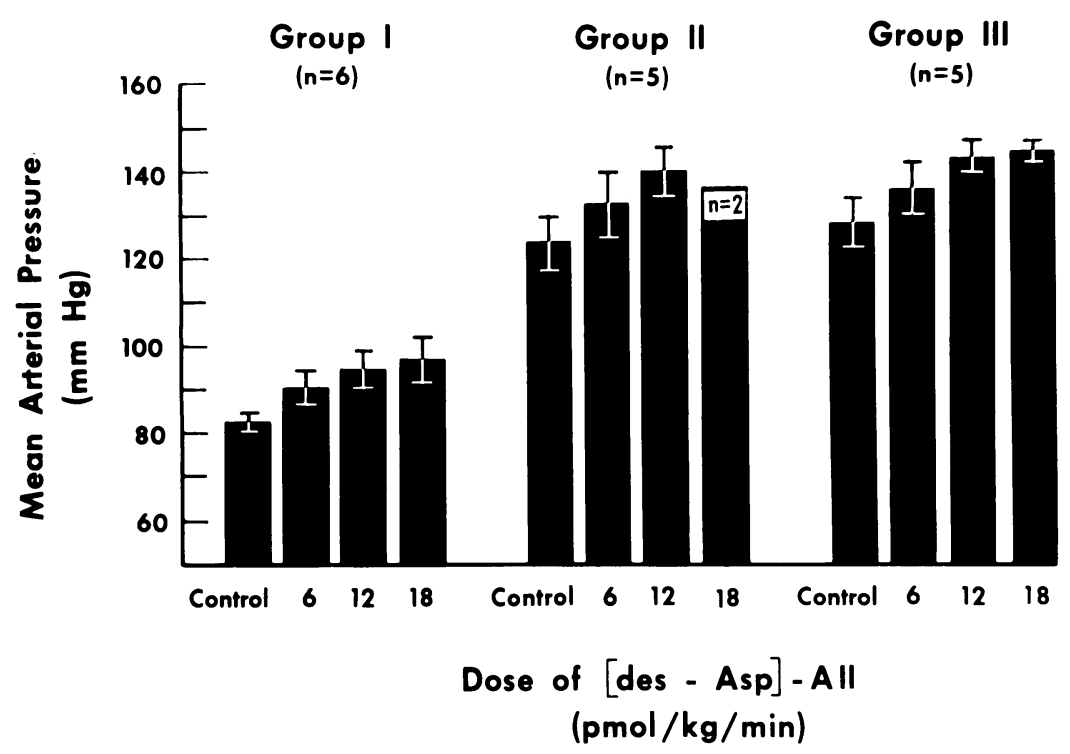

Figure 5 Blood pressure responses of subjects in the three study groups to [des-Asp)]AII infusion. Three of the subjects in group II received two cumulative doses of heptapeptide. All other subjects received three cumulative doses of heptapeptide.

concentration implies either an inadequate response of the endogenous renin-angiotensin system to upright posture or an inability of the adrenal adenoma to respond to the endogenous angiotensin stimulus. However, the consistent increase in plasma renin activity observed in the patients with APA after upright posture suggests that the defect in the renin-angiotensin-aldosterone system may occur after the release of renin.

In the present study, the increment in plasma aldosterone concentration in response to [des-Asp]-AII administration was greater in angiotensin-responsive patients with primary aldosteronism (group II) than in normotensive control subjects (group I). However, the percentage change of aldosterone from base line in group II as well as in the patients with IHA was not different significantly from that of group I. Thus, although aldosterone responsiveness to an angiotensin stimulus was documented in patients with IHA and a subset of patients with APA, hyperresponsiveness to [des-Asp]-AII was not observed. These results differ from those reported in a preliminary communication showing that patients with IHA have increased adrenal sensitivity to AII (20). These differences in results with respect to the IHA patients may be attributable to differences in the molar quantity of peptide administered, differences in the amino acid composition of the two peptides or the use of supplemental sodium and dexamethasone to minimize the influence of endogenous AII and ACTH that study (20). The results of the present study are consistent with the observation from our laboratory that exogenous suppression of the renin-angiotensin system by high sodium intake and propranolol in normotensive man does not alter adrenal responsiveness appreciably to [des-Asp]-AII (21). Thus, the degree of angiotensin-induced responsiveness is not affected by the level of plasma renin activity per se.

During the [des-Asp]-AII infusions, serum potassium and plasma cortisol concentrations were unchanged. excluding potassium and adrenocorticotrophic hormone as factors responsible for increased aldosterone production during the infusion studies $(22-26)$.

Previous attempts to stimulate aldosterone with AII in primary aldosteronism have been reported. Slaton et al. (27), found that only 2 of 12 patients with APA responded, but the dose was limited by a marked pressor effect. Wenting et al. (28) used a larger dose of AII, and in spite of a 40-mm $\mathrm{Hg}$ increase in mean arterial blood pressure, found stimulation of aldosterone in 4 of 10 patients with primary aldosteronism. However, only one patient diagnosed as having APA who showed aldosterone stimulation had pathologic confirmation of the diagnosis and cure of hypertension with resection of the adrenal adenoma. In direct contrast to the results of the present study, Spark and co-workers (29) found that aldosterone secretion of patients with APA increased markedly with a 6-h infusion of AII at a dose sufficient to maintain mean arterial blood pressure $10 \mathrm{~mm} \mathrm{Hg}$ above base line. The reasons for the differences between the results of this and the present study are not clear, but may be related to differences in the dose, duration of infusion, or amino acid composition of the peptide administered.

Failure to suppress plasma renin activity with 
[des-Asp]-AII in patients with primary aldosteronism (groups II and III) as opposed to the control population (group I) suggests altered regulation of renin release. This observation is consistent with the results of Williams et al. (30) who, in normotensive subjects, suppressed plasma renin activity with AII infusion, but not in patients with essential hypertension. Failure of [des-Asp]-AII to decrease plasma renin activity in patients with primary aldosteronism cannot be attributed solely to the degree of basal renin suppression, because normotensive subjects with plasma renin activity lowered to comparable levéls by high salt intake and propranolol still show significant suppression of plasma renin activity with [des-Asp]-AII (21).

Our results suggest a uniform pressor response to [des-Asp]-AII in all patients with primary aldosteronism and in normal control subjects, but either adrenal responsiveness or no response in primary aldosteronism. Whether this differential aldosterone response in primary aldosteronism reflects a parallel division into two subgroups of APA or a sequential tumor change from $(a)$ posture and [des-Asp]-AII responsive to $(b)$ posture unresponsive, [des-Asp]-AII responsive to $(c)$ posture and [des-Asp]-AII unresponsive cannot be determined by this study, and would require a longitudinal study of patients with APA who initially respond to [des-Asp]-AII.

\section{ACKNOWLEDGMENTS}

This work was supported by U. S. Public Health Service General Clinical Research Center grant RR-841 and in part by National Institutes of Health Research grant HL-22306.

\section{REFERENCES}

1. George, J. M., J. Wright, R. H. Bell, and F. C. Bartter. 1970. The syndrome of primary aldosteronism. Am. J. Med. 48: 343-356.

2. Biglieri, E. G., J. R. Stockiigt, and M. Schambelan. 1972. Adrenal mineralocorticoids causing hypertension. Am. J. Med. 52: 623-632.

3. Horton, R. 1969. Stimulation and suppression of aldosterone in plasma of normal man and in primary aldosteronism. J. Clin. Invest. 48: 1230-1236.

4. Cain, J. P., M. L. Tuck, G. H. Williams, R. H. Dluhy, and S. H. Rosenoff. 1972. The regulation of aldosterone secretion in primary aldosteronism. Am. J. Med. 53: 627-637.

5. Ganguly, A., A. J. Dowdy, J. A. Luetscher, and G. A. Melada. 1973. Anomalous postural response of plasma aldosterone concentration in patients with aldosterone producing adenoma. J. Clin. Endocrinol. Metab. 36: 401-404.

6. Ganguly, A., G. A. Melada, J. A. Luetscher, and A. J. Dowdy. 1973. Control of plasma aldosterone in primary aldosteronism: distinction between adenoma and hyperplasia. J. Clin. Endocrinol. Metab. 37: 765-775.

7. Luetscher, J. A., A. Ganguly, G. A. Melada, and A. J.
Dowdy. 1974. Preoperative differentiation of adrenal adenoma from idiopathic adrenal hyperplasia in primary aldosteronism. Circ. Res. 34 and 35(Suppl. I): 175-182.

8. Biglieri, E. G., M. Schambelan, N. Brust, B. Chang, and M. Hogan. 1974. Plasma aldosterone concentration, further characterization of aldosterone producing adenomas. Circ. Res. 34 and 35(Suppl. I): 183-189.

9. Schambelan, M., N. L. Brust, G. C. F. Chang, K. L. Slater, and E. G. Biglieri. 1976. Circadian rhythm and effect of posture on plasma aldosterone concentration in primary aldosteronism. J. Clin. Endocrinol. Metab. 43: 115-131.

10. Kono, T. F., F. Oseko, S. Shimpo, M. Nanno, and J. Endo. 1975. Biological activity of des-asp ${ }^{1}$-angiotensin II (angiotensin III) in man. J. Clin. Endocrinol. Metab. 41: 1174-1177.

11. Carey, R. M., E. D. Vaughan, Jr., M. J. Peach, and C. R. Ayers. 1978. Activity of [des-aspartyl $\left.{ }^{1}\right]$-angiotensin II and angiotensin II in man. J. Clin. Invest. 61: 20-31.

12. Carey, R. M., J. G. Douglas, J. R. Schweikert, and G. W. Liddle. 1972. The syndrome of essential hypertension and suppressed plasma renin activity: normalization of blood pressure with spiroholactone. Arch. Intern. Med. 130: 849-854.

13. Carey, R. M., E. D. Vaughan, Jr., J. A. Ackerly, M. J. Peach, and C. R. Ayers. 1978. The immediate pressor effect of saralasin in man. J. Clin. Endocrinol. Metab. 46: $36-43$.

14. Spark, R. F., and J. C. Melby. 1968. Aldosteronism in hypertension: the spironolactone response test. Ann. Intern. Med. 69: 685-691.

15. Bühler, F. R., J. E. Sealey, and J. H. Laragh. 1974. Radioimmunoassay of plasma aldosterone. In Hypertension Manual. J. H. Laragh, editor. Dun-Donnelley Publishing Corp., New York. 655-672.

16. Sealey, J. E., J. H. Laragh, J. Gertew-Banes, and R. M. Aceto. 1974. The measurement of plasma renin activity in man. In Hypertension Manual. J. H. Laragh, editor. Dun-Donnelley Publishing Corp., New York. 621-640.

17. Mattingly, D. 1962. A simple fluorometric method for estimation of free 11-hydroxy-corticoids in human plasma. J. Clin. Pathol. (Lond). 15: 374-379.

18. Ames, R. P., A. J. Borkowski, A. M. Sicinski, and J. H. Laragh. 1965. Prolonged infusion of angiotensin II and norepinephrine and blood pressure, electrolyte balance and aldosterone and cortisol secretion in normal man and in cirrhosis with ascites. J. Clin. Invest. 44: 1171-1186.

19. Wisgerhof, M., and R. D. Brown. 1978. Increased adrenal sensitivity to angiotensin II in low renin essential hypertension. J. Clin. Invest. 61: 1456-1462.

20. Wisgerhof, M. and R. D. Brown. 1978. Increased adrenal sensitivity to angiotensin II in low-renin essential hypertension and idiopathic hyperaldosteronism. Clin. Res. 26: 31A. (Abstr.)

21. Carey, R. M., M. J. Peach, E. D. Vaughan, Jr., and C. R. Ayers. 1978. Effects of renin suppression on responses to angiotensins II and III in man. Clin. Res. 26: 361A. (Abstr.)

22. Baumann, K., and J. Müller. 1972. Effect of potassium intake on the final steps of aldosterone biosynthesis in the rat. I. 18-hydroxylation and 18-hydroxyhydrogenation. Acta Endocrinol. 69: 701-717.

23. Baumann, K., and J. Müller. 1972. Effect of potassium intake on the final steps of aldosterone biosynthesis in the rat. II. 11- $\beta$-hydroxylation. Acta Endocrinol. 69: $718-730$. 
24. Newton, M. A., and J. H. Laragh. 1968. Effect of corticotropin on aldosterone excretion and plasma renin in normal subjects, in essential hypertension and in primary aldosteronism. J. Clin. Endocrinol. Metab. 28: 1006-1013.

25. Biglieri, E. G., M. Schambelan, and P. E. Slaton, Jr. 1969. Effect of adrenocorticotropin on desoxycorticosterone, corticosterone and aldosterone excretion. J. Clin. Endocrinol. Metab. 29: 1090-1101.

26. Kem, D. C., M. H. Weinburger, C. Gomez-Sanchez, M. J. Kramer, R. Lerman, S. Furuyama, and C. A. Nugent. 1973. Circadian rhythm of plasma aldosterone concentration in patients with primary aldosteronism. J. Clin. Invest. 52: 2272-2277.

27. Slaton, Jr., P. E., M. Schambelan, and E. G. Biglieri.
1969. Stimulation and suppression of aldosterone secretion in patients with an aldosterone producing adenoma. J. Clin. Endocrinol. Metab. 29: 239-250.

28. Wenting, G. J., A. J. Man, In't Veld, F. H. Derkx, P. V. Brummelen, and M. A. D. H. Schalekamp. 1978. ACTHdependent aldosterone excess due to adrenal cortical adenoma: a variant of primary aldosteronism. J. Clin. Endocrinol. Metab. 46: 326-335.

29. Spark, R. F., S. L. Dale, P. C. Kahn, and J. C. Melby. 1969. Activation of aldosterone secretion in primary aldosteronism. J. Clin. Invest. 48: 96-104.

30. Williams, G. H., N. K. Hollenberg, T. J. Moore, R. G. Dluhy, S. Z. Bauli, H. S. Solomon, and J. H. Marsey. 1978. Failure of renin suppression by angiotensin II in hypertension. Circ. Res. 42: 46-52. 